\title{
Dying Embers: Fire-lighting Technology and Mortuary Practice in Early Bronze Age Britain
}

DOI:

10.1080/00665983.2016.1177258

\section{Document Version}

Accepted author manuscript

Link to publication record in Manchester Research Explorer

\section{Citation for published version (APA):}

Teather, A., \& Chamberlain, A. (2016). Dying Embers: Fire-lighting Technology and Mortuary Practice in Early Bronze Age Britain. The Archaeological Journal, 173(2), 188-205. https://doi.org/10.1080/00665983.2016.1177258

\section{Published in:}

The Archaeological Journal

\section{Citing this paper}

Please note that where the full-text provided on Manchester Research Explorer is the Author Accepted Manuscript or Proof version this may differ from the final Published version. If citing, it is advised that you check and use the publisher's definitive version.

\section{General rights}

Copyright and moral rights for the publications made accessible in the Research Explorer are retained by the authors and/or other copyright owners and it is a condition of accessing publications that users recognise and abide by the legal requirements associated with these rights.

\section{Takedown policy}

If you believe that this document breaches copyright please refer to the University of Manchester's Takedown Procedures [http://man.ac.uk/04Y6Bo] or contact uml.scholarlycommunications@manchester.ac.uk providing relevant details, so we can investigate your claim.

\section{OPEN ACCESS}




\title{
Dying Embers: Fire-lighting Technology and Mortuary Practice in Early Bronze Age Britain
}

\author{
Anne Teather and Andrew Chamberlain \\ In me thou see'st the glowing of such fire \\ That on the ashes of his youth doth lie, \\ As the death-bed whereon it must expire \\ Consum'd with that which it was nourish'd by.
}

Shakespeare, Sonnet 73

We examine the known examples of strike-a-light kits within prehistoric mortuary contexts in mainland Britain. Building on the seminal work of Clarke in the 1970s and Needham's recent work on Beaker grave groups, many further examples of this burial practice are documented from both historic and recent excavations. It is evident that strike-a-light kits have a considerable longevity in prehistoric mortuary practice, with all but one dating to between $\mathrm{c}$. $2500 \mathrm{cal}$. BC and c. $1500 \mathrm{cal}$. BC. Our analysis presents new radiocarbon dates and data from stable isotope studies of human remains that indicate the practice reached a peak between c. 2200 and c. 2000 cal. BC. Strike-a-light kits appear to be associated both with individuals born local to their burial place as well as those born at a considerable geographical distance. It is argued that strike-a-light kits had a particular significance in the burial of adult males and that kits were symbolic inclusions rather than being linked to the practice of fire-lighting during the men's life-time in this period.

\section{INTRODUCTION}

Mortuary practices in prehistoric Britain present a diverse and complex pattern that changed through time. It is commonly understood that during the early and middle Neolithic periods (c. 4000-2500 cal BC) collective burial was the norm (Fowler 2010), with burials during the following Late Neolithic/Chalcolithic (or Primary Beaker period: c. 2500-2200 cal. BC, prior to the 'Fission Horizon': Needham 2005; 2012) and Early Bronze Age (or Phases 2-3 Beaker 
periods: c. 2200-1600 cal. BC) more often being made individually, frequently within barrows and typically accompanied by grave-goods (ibid.). In the Middle Bronze Age (from c. 1600 cal. BC) cremation became the predominant form of processing the dead (Brück 2009). Overall this period of time - $c .2500 \mathrm{cal}$. $\mathrm{BC}$ to $c .1500 \mathrm{cal} . \mathrm{BC}-$ is seen as containing changes that demonstrate the transition between the Neolithic and Bronze Age in Britain, when metalworking is introduced for the first time and by the end of the period, agricultural and settlement practices were more intensive. In this study we contribute to the debate about the meaning of grave-goods during this thousand year period by investigating the deposition of strike-a-light kits within graves. Our work builds on that of Clarke (1970, 264-65, 448) who drew attention to the close association of strike-a-lights with male burials of his Northern British and Southern British Beaker burial groups. Subsequently, the work of Needham $(2005 ; 2012)$ highlighted the importance of strike-a-light kits as an 'artefact association group' found in both primary and post-Fission Horizon Beaker traditions spanning the Late Neolithic/Early Bronze Age transition. Effectively, new burial practices emerge at c. $2500 \mathrm{cal}$. BC that have a distinct character and a noticeable chronological development that has been studied in many ways, strike-a-light kits being noted as an artefact group from early examples.

Commonly referred to as the Beaker period in Britain, it is characterized by the introduction of continental styles of pottery, the beginnings of metalworking in copper and gold, and the burial of individuals with sets of grave-goods that in some instances may have indicated the wealth or prestige of the deceased. Interpretations of this shift have been qualified and revised from various perspectives in recent years, including Gibson (2007) who discusses Neolithic antecedents of these burial practices in Britain, and Fokkens (2012) who provides an alternative to the interpretation of grave-goods as indicators of wealth. Still, the distinctive 
shift in the archaeological record of grave-goods with burials during the Primary Beaker and subsequent Beaker phases have been subject to much analysis, concurrent with studies of other grave attributes including body orientation and gender (Clarke 1970; Needham 2005; 2012; Sheridan 2007; Shepherd 2012; Fokkens 2012; Frieman 2014; Fowler 2015; Hunter and Woodward 2015). These studies show that there are normative associations in Beaker burial practice that encompass particular sets of artefacts and the position, orientation and gender of the body. However, these associations vary across and even within regions. In following one set of artefacts in graves at this time — strike-a-light kits — we intend to investigate the presence and possible symbolic associations of these superficially mundane and utilitarian items.

\section{STRIKE-A-LIGHTS}

'Strike-a-light', also referred to in some previous literature as a 'fire-kit', is a term used to denote a particular grouping of artefacts that together provide the means to make a spark that is sufficiently hot to start a fire (Nieszery 1992; Stapert and Johansen 1999; Sorensen et al. 2014). This specialized tool kit commonly consists of a striker (a piece of flint or other silicacontaining material that often exhibit a convex edge), tinder (for example dry moss, or the tinder fungus Fomes fomentarius) and a strike-stone (a piece of metallic or sulphuric iron, usually a nodule of the closely similar iron sulphide minerals, iron pyrites or marcasite, Illus 1.). When the flint and iron mineral are struck together they produce a spark which may ignite the tinder.

The flint/pyrites striking method seems to have been the dominant form of fire-making used in European prehistory (Stapert and Johansen 1999; Sorensen et al. 2014). However a spark could have been obtained from pyrites using many types of edged flint artefacts; the handles 
of flint daggers were used as strikers in Early Bronze Age Schleswig-Holstein (Nieszery 1992, 361) and miniature flint daggers placed in Danish graves were used to the same effect (Petersen 1993, 141; Stapert and Johansen 1999, 367). Strike-stones can demonstrate usewear in the form of single or multiple groove marks (Nieszery 1992), as seen at Rudston (Illus. 2, Greenwell 1877, 264), Basingstoke (Anon. 1883) and in the Amesbury Archer's grave (Illus. 3, Harding 2011, 102, fig. 39, 118). Usually only the component parts of striker and/or the strike-stone are recovered archaeologically as evidence of the presence in a burial of a strike-a-light kit - the archaeological survival of tinder is almost unique to the Ötztaler 'ice man' (or Ötzi, Spindler 1994). However iron pyrites nodules may also be archaeologically absent as they commonly entirely corrode through oxidization, particularly in acidic soil conditions, producing various mineral breakdown products dependent on the environmental conditions (Nordstrom 1982). Traces of mineral elements in the form of a rust-colour staining have been noted during some excavations, and these have been mineralogically tested in two studies, at the Neolithic cemeteries of Aiterhofen-Ödmühle cemeteries in lower Bavaria (Niezery 1992, 363) and at Ostorf in north-eastern Germany (Friedrich 2007, 418). These tests identified goethite, one of the possible products of the decomposition of pyrite or marcasite, strongly suggesting the past inclusion of a pyrite strike-stone in the grave. Haematite (red ochre) and limonite (yellow ochre) are also possible products of the breakdown of iron pyrites (Nordstrom 1982). Therefore the identification of any of these within a grave could be indicative of a pyrite inclusion within the mortuary context. Due to the variability in the preservation and archaeological retrieval of iron pyrites, it has been argued on the continent that it is useful to view the striker on its own as an indicator of a strike-a-light kit having been included in the grave (Niezery 1992, 363; Friedrich 2007, 41718). A single striker may also have served as a synecdoche within the mortuary context, the part standing for the whole of the kit (Tilley 1999, 6). Adopting that criterion would no 
doubt facilitate recognition of further examples of this cultural practice, which may be a useful avenue for future research.

\section{STRIKE-A-LIGHTS FROM BURIAL CONTEXTS IN PREHISTORIC}

\section{BRITAIN}

We have identified fifty-two probable examples of strike-a-lights deposited in prehistoric burial contexts ('strike-a-light burials') from mainland Britain, located at sites distributed throughout the country from the south coast of Cornwall to northern Scotland (Table 1; Illus. 4). The occurrences have been identified through analyses of excavation records where the strike-stone (in all but four cases identified as iron pyrites or marcasite) and/or a flint striker has been noted during excavation. Six of the examples were not demonstrably associated with human remains, and of the forty-six where details of the burial context are known, thirtythree (or $72 \%$ ) were found in inhumation graves, twelve derived from cremation burials and one from a dual inhumation/cremation (28\%). Of the twenty sexed human remains associated with strike-a-lights, the overwhelming majority of occurrences are male (90\%) with just two examples associated with possible females at Nether Low (Bateman 1861, 52) and Amesbury G58 (Ashbee 1985, 70).

Whilst only a third of the sites have been radiocarbon dated, diagnostic artefacts can be used to broadly categorize the chronological duration of burials with this kit. Only one site is likely to date to the middle Neolithic: Crosby Garrett 174. This dating is based on the inclusion of an antler macehead (Greenwell 1877, 389-91) which resembles examples from other sites that have been directly dated to the second half of the fourth millennium cal. BC (Loveday et al. 2007). Seventeen radiocarbon dates are available with thirteen of these being direct dates on human bone. These radiocarbon determinations have been calibrated with OxCal 4.2 using 
the IntCal 13 atmospheric calibration curve and are presented in Table 2. The majority of these calibrated dates fall into the second half of the third millennium $\mathrm{BC}$ and only five are likely to post-date 2000 cal. BC. It should be noted, however, that only two of the thirteen cremation burials in this dataset have been radiocarbon dated. The earliest dated examples are found in Wessex (sites in Hampshire and Wiltshire) and in Scotland. The Wessex sites, which include some of the earliest dated Beaker burials, are Chilbolton, the Amesbury Archer and the Boscombe Bowman: the latter two sites being less than $1 \mathrm{~km}$ apart and Chilbolton within $20 \mathrm{~km}$ of both of them. In Scotland, Upper Largie near Kilmartin and Dornoch in Easter Ross are the earliest but separated from each other by over $130 \mathrm{~km}$. The latest radiocarbon dated site in Scotland is Dunfermline (3581 $\pm 40,2040-1780$ cal. BC, SRR-292) but strike-a-lights continue to appear in graves in England with Beaker pottery after $1800 \mathrm{BC}$, at Amesbury G58 and at Barrow Hills (Illus. 5). However, the pottery items within these burials are likely to be curated or residual as the Beaker dates here are thought to be very late (Needham 2005; Sheridan 2007; Healy 2012).

A number of the burials with strike-a-lights stand out due to the quality of goods within the deposit (Table 1). These include some of the most wealthy single graves of this period (e.g. Kirkhaugh, Amesbury Archer and Acklam Barrow). Removing Crosby Garrett 174 from the burial statistics above to enhance chronological sensitivity, twenty-four of the fifty-one grave contexts (47\%) contained valuable grave-goods (a category we define as including gold, copper, bronze, amber, jet and ornate stone artefacts following Woodward and Hunter 2015, 23 , though we have excluded bone/antler artefacts such as spatulas and pins). Therefore this categorisation of almost half the examples as being wealthy graves is likely to be considerably higher than the average for the Beaker period. For example, using the same wealthy grave definition to the 189 male Beaker burials included in the Beaker Isotope 
Project, less than $10 \%$ included valuable grave-goods with a similar proportion for female graves (Parker Pearson et al., forthcoming) and of 218 excavated Bronze Age burial mounds in Derbyshire, approximately $20 \%$ contained valuable goods (based on data taken from Marsden 1994). It is possible that the archaeological retrieval of strike-a-light kits is enhanced within multi-artefact mortuary contexts.

Of the twenty sets of human remains where we have an estimation of biological sex, nineteen are from inhumations and one from a cremation. Of these, eighteen inhumations are thought to be male $(95 \%)$ and one possibly female $(5 \%)$ with the one sexed cremation of thirteen examples thought to be female. While Brück $(2009,4-5)$ has suggested that a higher proportion of females than males were subjected to cremation in the Bronze Age (based on data from mainly post-1980 excavations with reliable osteoarchaeological reports), cremated remains with strike-a-light kits represent less than one third of all examples. Thus our data overwhelmingly suggest that these kits were associated with males.

\section{PARALLELS ON THE NEAR CONTINENT}

Both Denmark and France have examples of strike-a-light burials that are contemporary with those in Britain. In his discussion of sixty-six Danish Beaker archery burials, Sarauw (2007, 69-70, 72) notes three graves with strike-a-lights at Solbakkegård IV, Ved Rammediget and Kjærgård dating to c. 2350 BC-1950 BC (Sarauw 2007, 66). A further ten graves with strikea-lights dating to the Danish Middle Bronze Age period IB (1600 BC-1500 BC) have been catalogued by Bergerbrant (2007, Appendix 1) though a late example is noted at Diverhøj and dated to the beginning of Bronze Age period II (c. 1500 cal. BC, Asingh 1987, 135, 152; see also Olsen et al. 2011). Beaker period graves containing flint strikers ('briquets') together with pyrite nodules and/or iron oxide staining on the strikers have also been found in northern 
France and Luxembourg dating to between 2500 and 2100 cal. BC (Salanova and Tcheremissinoff 2011).

Further, there are examples on the near Continent that could be contemporary with the anomalously early British example of Crosby Garrett 174. Schipluiden, on the coast of the Netherlands, is a Neolithic settlement dated to 3600-3400 cal. BC (Smits and Lowe Kooijmans 2006, 97). Here, Grave 2 contained a tightly flexed male inhumation burial with his hands positioned by his face and enclosing a strike-a-light set of three flint artefacts and a nodule of pyrite. Near Schwerin in northern Germany the site of Ostorf is a flat grave cemetery of forty inhumations on an island within the Ostorfer See. The site included grave III/35 with a strike-a-light kit that is dated to $c .3000$ cal. BC (Bastian 1961; Friedrich 2007; Lübke et al. 2009, 324, 330). Nine other graves at this site have been identified as burials with strike-a-lights. Further examples of pyrites nodules have been noted in graves contemporary to Ostorf at Dreetz, Pevestorf, Walternienburg and Tangermünde (Friedrich 2007, 421).

\section{INTERPRETATIONS OF THE STRIKE-A-LIGHT BURIAL RITE}

It has been suggested that strike-a-light kits found with the Amesbury Archer and in grave 2 at Schipluiden were connected with travel and the need to light one's own fire while journeying (Smits and Louwe Kooijmans 2006; Fitzpatrick 2009;). However, were these journeys that had been completed during the deceased's lifetime, or are we instead seeing symbolic reference to journeys to be commenced in the afterlife? Stable isotope data are beginning to reveal the origins of some individuals buried with strike-a-lights, with the preliminary data indicating considerable geographical mobility within this group between their places of childhood and burial (Table 3). The Amesbury Archer is known to be a 
migrant from the Continent with a childhood spent in a geographical zone as far to the east as Scandinavia or Germany (Chenery and Evans 2011, 188-90). The strontium and oxygen isotope signatures of the Boscombe Bowmen, including the strike-a-light burial 25004, are consistent with non-local origins in the north or west of Britain, or alternatively from more distant origins either in southeast Ireland or continental Europe (Chenery and Evans 2011, 186-90). The mixture of local and distant origins inferred from the stable isotope data (Table 3) are consistent with the overall results of the Beaker People Project in which about one third of sampled individuals had moved between region of birth and region of burial (Parker Pearson et al. forthcoming). Although some degree of residential mobility appears to be characteristic of all periods of British prehistory the continental-scale migration evidenced in the Beaker period was not observed in a study of an earlier Neolithic population (Neil et al., 2016). Of the eight examples listed in Table 3, four appear to have local origins, two are definite migrants from continental Europe and the other two are migrants with possible continental origins. Thus the extent of residential mobility in the individuals buried with strike-a-lights may have been typical of their communities and it does not necessarily imply that the inclusion of a strike-a-light kit as a personal grave-good symbolised actual travel that had taken place by the deceased during the their lifetime.

For the continental European examples he has studied, Nieszery $(1992,368)$ suggested that individuals buried with strike-a-light kits may have been travellers who were periodically absent from their community. He suggests the reason for this may have been for activities such as shepherding or hunting, but also notes the association of old men with fire lighting equipment at Aiterhofen. Nieszery observes that a younger man aged at approximately 20-30 years old in grave 55 appears to have a shortened right leg after sustaining a fracture of the femur and, as a result of this, would have had a severe limp. Nieszery $(1992,368)$ uses this 
burial to argue that perhaps some male individuals who were unable to complete physical activities outside the settlement would have been called upon to maintain the fires. The Amesbury Archer provides another example of impaired mobility due to disability; he appears to have suffered from a chronic debilitating infection of the left knee joint and was missing a patella (McKinley 2011). The Ötztaler 'ice man' (or Ötzi, Spindler 1994) also exhibited arthritic changes in the joints of his spine, knees and ankles.

These competing interpretations, based alternately on evidence for mobility versus immobility, both rely on viewing strike-a-light kits as functional tools habitually used by the deceased individual in their lifetime. An alternative interpretation is offered, based on an exploration of the metaphorical associations between material culture, and notions of death and the afterlife as illustrated by the quotation from Shakespeare's sonnet at the start of this paper. Death has common metaphoric associations within literature (Lakoff and Turner 1989) that could, as Tilley $(1999,79)$ suggests, become enacted as solid metaphors through the use of particular material culture. Lakoff and Turner $(1989,8-14,52)$ describe the many metaphors for death in language: that life is often perceived as a journey, and death as the final destination. Hence in modern Western cultures we often refer to a new baby not having yet 'arrived' and someone close to death as 'passing away'. Another common metaphor Lakoff and Turner cite is that life is light and warm, and death is dark and cold. This is perhaps pertinent to our subject. If the strike-a-light kits accompanying biological male burials are related to metaphorical understandings of life and death in this way, then we may be seeing an aspect of prehistoric ritual where biological males are perceived as taking the journey to death in a different way to females. It could be that in terms of religious belief, some men required fire-lighting technology to help them negotiate the darkness and cold of death. Their journey might be longer, or take a more perilous route. The examples of older men and those 
with disabilities may be of relevance here as their journey may be impeded by their compromised mobility. The fire they can create themselves through the strike-a-light kits, providing warmth and light, may make the difference between a successful or disastrous transition to the afterlife.

Strike-a-light kits seem to disappear from burial assemblages at the start of the Middle Bronze Age, at a time when fire seems to have taken on an extended array of transformative roles in material production as well as in ritual activities (MacGregor 2008). At this time cremation becomes the predominant method for the transformation of the corpse; the construction of numerous burnt mounds testifies to the extensive use of fire-heated stones to heat water (and perhaps generate steam), and there is a very substantial increase in the smelting of ores for the production of bronze tools and weaponry. With intensification of settlement and the rise of industrial production the symbolic associations of fire may have changed, with the idea of fire as nourishing the deceased traveller being replaced by the concept of fire as an agent for transforming the material world.

\section{CONCLUSION}

This paper has discussed the deposition of strike-a-light kits within British and northern European prehistoric mortuary contexts. In Britain only one instance of this practice appears contemporaneous with early continental examples; Crosby Garrett 174, dating to the middle Neolithic $c$. 3500-3000 BC. The remaining examples emerge with the single grave tradition at the beginning of the Beaker period and are related to the Beaker package. Of those dated radiometrically, the majority fall between $2500 \mathrm{BC}$ and $2000 \mathrm{BC}$, and are therefore broadly contemporaneous with similar examples in Denmark, northern France and Luxembourg. 
They have been found throughout mainland Britain, with noticeable clusters occurring in areas of intensively excavated prehistoric monuments, notably Wessex, the Peak District and East Yorkshire. The current data suggests that this was a burial custom particularly related to being biologically male. Strike-a-lights provide autonomy for a person in creating fire, whether for heating, light or cooking. The final journey for early Bronze Age men may have been perceived as lonely and cold, with little comfort along the way. These degraded scraps of stone might have had far more of an emotive component than previously imagined.

\section{ACKNOWLEDGMENTS}

We would like to thank Mike Parker Pearson for commenting on a draft of this paper and allowing us to use some of the forthcoming Beaker People Project data, Tosca Friedrich who kindly provided us with a copy of her paper and anonymous referees for suggestions to improve the paper. We are grateful to Jim Rylatt who tracked down some examples we had not located. This paper was initially presented at the Bronze Age Forum (University of Exeter 2015) and we are grateful to Rob Wiseman for his thoughtful direction to Lakoff and Turner.

\section{BIBILIOGRAPHY}

ALLEN, M. J., GARDINER, J. and SHERIDAN, A. (eds) Is There a British Chalcolithic?

People, Place and Polity in the Later 3rd Millennium, Oxford: Oxbow

ANON. 1883. The Reliquary and Illustrated Archaeologist, 24, 128

ASHBEE, P. 1985. The excavation of Amesbury barrows 58, 61a, 61 and 72, Wiltshire Archaeol. Nat. Hist. Mag., 85, 140-41 
ASHMORE, P. J. 1989. Excavation of a Beaker cist at Dornoch Nursery, Sutherland, Proc. Soc. Antiq. Scot., 119, 63-71

ASINGH, P. 1987. Diverhøj - a complex burial mound and a Neolithic settlement, J. Danish Archaeol., 6, 130-54

BARCLAY, A. and HALPIN, C. 1999. Excavations at Barrow Hills, Radley, Oxfordshire. Volume 1: the Neolithic and Bronze Age Monument Complex. Thames Valley Landscapes Monogr., 11, Oxford: Oxford Archaeological Unit

BASTIAN, W. 1961. Das jungsteinzeitliche Flachgräberfeld von Ostorf, Kreis Schwerin. Jahrbuch für Bodendenkmalpflege Mecklenburg-Vorpommern, 1961, 7-130

BATEMAN, T. 1848. Vestiges of the Antiquities of Derbyshire, and the Sepulchral Usages of its Inhabitants, from the Most Remote Ages to the Reformation, London: John Smith

BATEMAN, T. 1861. Ten Years Digging in Celtic and Saxon Grave Hills in the Counties of Derbyshire, Stafford and York, London: John Russell

BERGERBRANT, S. 2007. Bronze Age Identities: Costume, Conflict and Contact in Northern Europe 1600-1300 BC, Stockholm Stud. Archaeol. 43, Lindome: Bricoleur Press

BORLASE, W. C. 1872. Naenia Cornubiae, a descriptive essay, illustrative of the sepulchres and funereal customs of the early inhabitants of the County of Cornwall, London: Longmans, Green and Co.

BRONK RAMSEY, C. 2009. Bayesian analysis of radiocarbon dates. Radiocarbon, 51 (1), $337-60$

BRÜCK, J. 2009. Women, death and social change in the British Bronze Age, Norwegian Archaeol. Rev., 42, 1-23 
CAMPBELL, D. 1890. Notice of the discovery of a cist with urn and strike-light at Corran Ferry, Inverness-shire, Proc. Soc. Antiq. Scot., 24, 436-38

CANTRILL, T. C. 1898. The contents of a cairn at Ystradfellte, Co. Brecon, Archaeol. Camb., 15, 248-64

CASE, H. J. 1956. The Lambourn Seven Barrows, Berkshire Archaeol. J., 55, 15-31

CHENERY, C. A. and EVANS, J. A. 2011. A summary of the strontium and oxygen isotope evidence for the origins of Bell Beaker individuals found near Stonehenge, in Fitzpatrick 2011, 185-90

CLARKE, D. L. 1970. Beaker Pottery of Great Britain and Ireland, Cambridge: Cambridge University Press

CLARKE, D.V., COWIE, T. G. and FOXTON, A. 1985. Symbols of Power at the Time of Stonehenge, Edinburgh: National Museum of Antiquities of Scotland

CLOSE-BROOKS, J., NORGATE, M., and RITCHIE, J. N. G. 1974. A Bronze Age cemetery at Aberdour Road, Dunfermline, Fife, Proc. Soc. Antiq. Scot., 104, 121-36

COOK, M., ELLIS, C. and SHERIDAN, A. 2010. Excavations at Upper Largie Quarry, Argyll and Bute, Scotland: new light on the prehistoric ritual landscape of the Kilmartin Glen, Proc. Prehist. Soc., 76, 165-212

DAY, W. 1972. The excavation of a Bronze Age burial mound at Ysgwennant, Llansilin, Denbighshire, Archaeol. Camb., 122, 17-50

DYER, J. F. 1959. Barrows of the Chilterns, Archaeol. J., 116, 1-25

EVANS, J. 1897. The Ancient Stone Implements, Weapons and Ornaments, of Great Britain. London: Longmans, Green and Co. 
FASHAM, P. J., FARWELL, D. E. and WHINNEY, R. J. B. 1989. The Archaeological Site at Easton Lane, Winchester, Gloucester: Alan Sutton

FITZPATRICK, A. P. 2009. In his hands and in his head: the Amesbury Archer as a metalworker, in P. Clark (ed.) Bronze Age Connections: Cultural Contact in Prehistoric Europe, 176-88, Oxford: Oxbow

FITZPATRICK, A. P. 2011. The Amesbury Archer and the Boscombe Bowmen: Bell Beaker Burials at Boscombe Down, Amesbury, Wiltshire. Wessex Archaeology Report, 27, Salisbury: Wessex Archaeology

FOKKENS, H. 2012. Dutchmen on the move? A discussion of the adoption of the Beaker package, in Allen et al. (eds), 115-25

FOWLER, C. J. 2010. Pattern and diversity in the Early Neolithic mortuary practices of Britain and Ireland: contextualising the treatment of the dead, Documenta Praehistorica 2010, XXXVII, 1-22

FOWLER, C. J. 2015. Change and continuity in Early Bronze Age mortuary rites: a case study from Northumberland, in R. Brandt, H. Ingvaldsen and M. Prusac (eds) Death and Changing Rituals: Function and Meaning in Ancient Funerary Practices, 45-91, Oxford: Oxbow Books

FOX, C. 1939. Two Bronze Age Cairns in South Wales, Simondston and Pond Cairns, Coity Higher Parish Bridgend, Cardiff: National Museum of Wales

FRIEDRICH, T. 2007. The strike-a-lights from the Ostorf graves, in L. Larsson, F. Lüth_and T. Terberger (eds) Innovation and Continuity - Non-Megalithic Mortuary Practices in the Baltic, 415-28, Mainz: Zabern

FRIEMAN, C. J. 2014. Double edged blades: re-visiting the British (and Irish) flint daggers, Proc. Prehist. Soc., 80, 33-65 
GIBSON, A. 2007. A Beaker veneer? Some evidence from the burial record, in Larsson and Parker Pearson 2007, , 47-64

GREENWELL, W. 1877. British Barrows, a Record of the Examination of Sepulchral Mounds in Various Parts of England, Oxford: Clarendon Press

HARDING, P. 2011. Flint, Fitzpatrick (ed.), 88-103

HARDY, J. 1889. On British urns, found at Hoprig, near Cockburnspath, Berwickshire, History of the Berwickshire Naturalists Club, 12, 131-37

HARRISON, R. J. 1980. The Beaker Folk, London: Thames and Hudson

HEALY, F. 2012. Chronology, corpses, ceramics, copper and lithics in Allen et al. (eds), $144-63$

HUNTER, J. and WOODWARD, A. 2015. Ritual in Early Bronze Age Grave Goods: An Examination of Ritual and Dress Equipment from Chalcolithic and Early Bronze Age Graves in England, Oxford: Oxbow

LAKOFF, G. and TURNER, M. 1989. More Cool than Reason: A Field Guide to Poetic Metaphor, London: The University of Chicago Press

LARSSON, M. and PARKER PEARSON, M. (eds) 2007. From Stonehenge to the Baltic. Living with Cultural Diversity in the Third Millennium BC, Oxford: Brit. Archaeol. Rep. Int. Ser, 1692 LOVEDAY, R., GIBSON, A., MARSHALL, P. D, BAYLISS, A., BRONK RAMSEY, C. and VAN DER PLICHT, H. 2007. The antler maceheads dating project, Proc. Prehist. Soc., 73, 381-92

LÜBKE, H., LÜTH, F. and TERBERGER, T. 2009. Fishers or farmers? The archaeology of the Ostorf cemetery and related Neolithic finds in the light of new data, Bericht der RömischGermanischen Kommission, 88, 307-38 
MACGREGOR, G. 2008. Elemental bodies: the nature of transformative practices during the late third and second millennium bc in Scotland, World Arch., 40, 268-80

MACKENZIE, C. 1885. Notice of a cist, with an urn and strike-light of flint and pyrites, at Flowerburn, Ross-shire, Proc. Soc. Antiq. Scot., 19, 352-70

MARSDEN, B.M. 1994. The Burial Mounds of Derbyshire, Eldwick: Privately Printed MARYON, H. 1936. Excavation of two Bronze Age barrows at Kirkhaugh, Northumberland, Archaeologia Aeliana 4th Series, 13, 207-17

MCKINLEY, J. I. 2011. Human remains (graves 1236 and 1289), in Fitzpatrick, , 77-87

MORRISON, A. 1971. Cist burials and food vessels - some recent discoveries and rediscoveries in Western Scotland, Glasgow Archaeol. J., 2, 8-26.

MORTIMER, J.R. 1905. Forty Years' Researches in British and Anglo-Saxon Burial Mounds of East Yorkshire, London: Brown and Sons

MURRAY, H. K. and SHEPHERD, I. A. G. 2007. Excavation of a beaker cist burial with meadowsweet at Home Farm, Udny Green, Aberdeenshire, Proc. Soc. Antiq. Scot., 137, 3558

NEEDHAM, S.P. 1995. Chronology and periodisation in the British Bronze Age, Acta Archaeologica, 67, 121-40

NEEDHAM, S. 2005. Transforming Beaker culture in north-west Europe; processes of fusion and fission, Proc. Prehist. Soc., 71, 171-217

NEEDHAM, S. 2012. Case and place for the British Chalcolithic, in Allen et al. (eds), 1-26 NEIL, S., EVANS, J., MONTGOMERY, J. and SCARRE, C. 2016. Isotopic evidence for 
residential mobility of farming communities during the transition to agriculture in Britain. $R$. Soc. open sci. 3, 150522.

NIESZERY, N. 1992. Bandkeramische Feuerzeuge, Archäologisches Korrespondenzblatt 22, $359-76$

NOBLE, G. and BROPHY, K. 2011. Ritual and remembrance at a prehistoric ceremonial complex in central Scotland: excavations at Forteviot, Perth and Kinross, Antiquity, 85, 78780

NORDSTROM, D. K. 1982. Aqueous pyrite oxidation and the consequent formation of secondary iron minerals, in J. A. Kittrick, D. S. Fanning and L. R. Hossner (eds) Acid Sulfate Weathering, 37-56, Madison, Wisconsin: Soil Science Society of America Press

OLSEN, J., HORNSTRUP, K. M., HEINEMEIER, J., BENNIKE, P. and THRANE, H. 2011. Chronology of the Danish Bronze Age based on 14C dating of cremated bone remains, Radiocarbon, 53, 261-75

PARKER PEARSON, M., RICHARDS, M., CHAMBERLAIN, A. and JAY, M. (ed.) forthcoming. The Beaker People: Isotopes, Mobility and Diet in Prehistoric Britain, Oxford: Oxbow

PASSMORE, A. D. 1927. Fieldwork in N. Wiltshire 1926-28, Wiltshire Archaeol. Nat. Hist. Mag., 44, 240-45

PETERSEN, P. V. 1993. Flint fra Danmarks Oldtid, Copenhagen, Høst and Søn

PITT RIVERS, H. A. 1888. Excavations in Cranborne Chase near Rushmore 1880-1888. Vol. II : Excavations in Barrows near Rushmore; Romano-British Village, Rotherley; Winkelbury Camp; Barrows and Anglo-Saxon cemetery, Winkelbury Hill, London: Harrison and Sons 
PULL, J. 1932. The Flint Miners of Blackpatch, London: Williams and Norgate

ROBERTSON, A. 1855. Notes of the discovery of stone cists at Lesmurdie, Banffshire, containing primitive urns, \&c., along with human remains, Proc. Soc. Antiq. Scot., 1, 205-11

ROSEHILL, Lord. 1871. Notice of a group of cists at Teinside, in Teviotdale, Proc Soc. Antiq. Scot., 8, 135-39

RUSSEL, A. 1990. Two Beaker burials from Chilbolton, Hampshire, Proc. Prehist. Soc., 56, $133-72$

SALANOVA, L. and TCHÉRÉMISSINOFF, Y. (eds) 2011. Les Sépultures Individuelles Campaniformes en France, Gallia Préhistoire Supplement, 51, Paris: CNRS Éditions

SARAUW, T. 2007. Male symbols or warrior identities? The 'archery burials' of the Danish Bell Beaker Culture, J. Anthropol. Archaeol., 26, 65-87

SHEPHERD, A. 2012. Stepping out together: men, women and their beakers in time and space, in Allen et al. (eds), 257-80

SHERIDAN, A. 2007. Scottish Beaker dates: the good, the bad and the ugly, in Larsson and Parker Pearson (eds), 91-123

SMITH, I. F. and SIMPSON, D. D. A. 1964. Excavation of three Roman tombs and a prehistoric pit on Overton Down, Wiltshire Archaeol. Nat. Hist. Mag., 59, 68-85

SMITS, S. E. and LOUWE KOOIJMANS, L. P. 2006. Graves and human remains, in L.P. Louwe Kooijmans and P. F. B. Jongste (eds) Schipluiden - A Neolithic Settlement on the Dutch North Sea Coast c. 3500 cal. BC, 91-112. Leiden: Leiden University Press

SORENSEN, A., ROEBROEKS, W. and VAN GIJN, A. 2014. Fire production in the deep past? The expedient strike-a-light model, J.Archaeol.l Sci., 42, 476-86

SPINDLER, K. 1994. The Man in the Ice, London: Weidenfeld and Nicolson 
STAPERT, D. and JOHANSEN, L. 1999. Flint and pyrite: making fire in the Stone Age, Antiquity, 73, 765-77

STEAD, I. M. 1962. The excavation of Beaker burials at Staxton, East Riding, 1957, Yorks. Archaeol. J., 40, 129-44

TEMPUS REPARATUM, 1996. An Interim Statement on the Archaeological Excavations at Church Farm, Bierton, Aylesbury, Bucks., Unpublished report

TILLEY, C. 1999. Metaphor and Material Culture, London: Routledge

WATKINS, T. and SHEPHERD, I. A. G. 1980. A beaker burial at Newmill, near Bankfoot, Perthshire, Proc. Soc. Antiq. Scot., 110, 32-43

\section{Table Captions and Figure Legends}

Table 1 Evidence for strike-a-lights in British prehistoric mortuary contexts

Table 2 Radiocarbon dates from British strike-a-light burial sites

Table 3 Stable isotope data from strike-a-light burial sites 


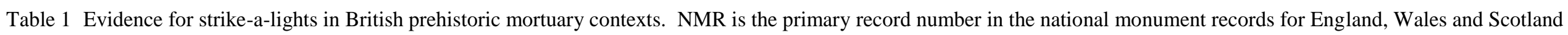

\section{Site (County/Authority)}

$\begin{array}{ll}\text { Sex } & \text { Burial } \\ M / F & \text { rite }\end{array}$

1 Acklam Barrow K4

(North Yorkshire)

2 Amesbury Archer

(Wiltshire)

3 Amesbury G58

(Wiltshire)

4 Angrouse Mullion Cairn (Cornwall)

5 Arbor Low Barrow (Derbyshire)

6 Auchencairn (Dumfries \& Galloway)

7 Barrow Hills Grave 203 (Oxfordshire)

$8 \quad$ Barrow Pleck 21 (Wiltshire)

9 Basingstoke (Hampshire)

10 Bierton with Broughton (Buckinghamshire)

11 Bishopstone (N) G1 (Swindon)

12 Blackpatch flint mine floor 2 (West Sussex)
Principal grave goods

Beaker, flint knife, flint dagger, jet and amber buttons

Beakers, copper daggers, gold artefacts, arrowheads, flint

knives, stone bracers

Bronze/copper dagger, Beaker

$\&$ Grooved ware (?associated)

MBA urn, bronze dagger

Food vessels, flint implement, bone pin

Beaker

Beaker, bronze awl, flint arrowheads and flakes, bone and antler tools

Pottery, flint flakes

Arrowheads

Beaker, barbed and tanged arrowheads

Animal bone

Flint tools
Pyrites Striker NMR

59725

Fitzpatrick 2011

219072

Ashbee 1985, 70

$425290 \quad$ Borlase 1872, 235

308656

66011

Clarke 1970, 516

1240966

Barclay \& Halpin 1999, 135-141 [Beaker possibly too late: Needham, 2005]

1301024 Pitt Rivers 1888, 5, 20

240668 Anon. 1883, 128

Tempus Reparatum 1996

$225592 \quad$ Passmore 1927

392607 Pull 1932, 60-62 


\begin{tabular}{|c|c|c|c|c|c|c|c|c|}
\hline 13 & $\begin{array}{l}\text { Boscombe } 25004 \\
\text { (Wiltshire) }\end{array}$ & M & $\mathrm{I}$ & $\begin{array}{l}\text { Beaker, flint, antler pendant, } \\
\text { boar's tusk }\end{array}$ & $\checkmark$ & $\checkmark$ & - & Fitzpatrick 2011 \\
\hline 14 & $\begin{array}{l}\text { Brigmerston, Milston G1 } \\
\text { (Wiltshire) }\end{array}$ & - & $\mathrm{C}$ & $\begin{array}{l}\text { Pottery, bone tool, worked } \\
\text { flints }\end{array}$ & $\checkmark$ & $\checkmark$ & 916889 & Evans 1897,314 \\
\hline 15 & $\begin{array}{l}\text { Brownedge } \\
\text { (Derbyshire) }\end{array}$ & - & $\mathrm{I}$ & Beaker, flint knife, jet button & $x$ & $\checkmark$ & 305868 & Bateman 1861, 38; Clarke 1970, 446 \\
\hline 16 & $\begin{array}{l}\text { Bulford Torstone } \\
\text { (Wiltshire) }\end{array}$ & - & $\mathrm{I}$ & $\begin{array}{l}\text { Food vessel, rock crystal, } \\
\text { boar's tusk, arrowheads }\end{array}$ & $\checkmark$ & $\checkmark$ & 1358757 & Parker Pearson (pers comm) \\
\hline 17 & $\begin{array}{l}\text { Chilbolton } \\
\text { (Hampshire) }\end{array}$ & - & $\mathrm{I}$ & $\begin{array}{l}\text { Beakers, gold artefacts, copper } \\
\text { dagger, antler spatula }\end{array}$ & $\checkmark$ & $\checkmark$ & 227356 & Russel 1990 \\
\hline 18 & $\begin{array}{l}\text { Corran Ferry } \\
\text { (Highland) }\end{array}$ & - & $\mathrm{U}$ & Beaker & $x$ & $\checkmark$ & 23580 & Campbell 1890; Clarke 1970, 517 \\
\hline 19 & $\begin{array}{l}\text { Corston } \\
\text { (Northeast Somerset) }\end{array}$ & M & I & Beaker, flint knife, flint tools & $\checkmark$ & $\checkmark$ & 201095 & Clarke 1970, 495 \\
\hline 20 & $\begin{array}{l}\text { Crosby Garrett } 174 \\
\text { (Cumbria) }\end{array}$ & M & $\mathrm{I}$ & Antler macehead, chert knife & $\checkmark$ & $\checkmark$ & 13180 & Greenwell 1877, 389-91 \\
\hline 21 & $\begin{array}{l}\text { Culduthel Mains } \\
\text { (Highland) }\end{array}$ & - & I & $\begin{array}{l}\text { Flint arrowheads, stone bracer, } \\
\text { amber bead, bone belt ring }\end{array}$ & $\checkmark$ & $\checkmark$ & 13519 & $\begin{array}{l}\text { Harrison 1980, 92-3; Clarke et al. } \\
1985,174\end{array}$ \\
\hline 22 & $\begin{array}{l}\text { Dornoch Nursery } \\
\text { (Highland) }\end{array}$ & - & $\mathrm{I}, \mathrm{C}$ & $\begin{array}{l}\text { Beaker, stone bracer, } \\
\text { arrowheads, Grooved ware }\end{array}$ & $\checkmark$ & $\checkmark$ & 14841 & Ashmore 1989; Sheridan 2007 \\
\hline 23 & $\begin{array}{l}\text { Dowe Lowe } \\
\text { (Derbyshire) }\end{array}$ & - & $\mathrm{I}$ & Bronze dagger, flint flakes & $\checkmark$ & $\checkmark$ & 305849 & Bateman 1848, 96 \\
\hline 24 & $\begin{array}{l}\text { Dunfermline Cist } 3 \\
\text { (Fife) }\end{array}$ & $? \mathrm{M}$ & $\mathrm{I}$ & Food vessel, flint knife & $\checkmark$ & $\checkmark$ & 50851 & Close-Brooks et al. 1974 \\
\hline 25 & $\begin{array}{l}\text { Dunstable Downs } \\
\text { (Bedfordshire) }\end{array}$ & $? \mathrm{M}$ & $\mathrm{I}$ & Pottery, flint flakes & $\checkmark$ & $\checkmark$ & 359953 & Dyer 1959,15 \\
\hline 26 & $\begin{array}{l}\text { Easton Lane } \\
\text { (Hampshire) }\end{array}$ & M & I & $\begin{array}{l}\text { Antler rods, bone awl, arrow- } \\
\text { heads, flint knife and flakes }\end{array}$ & $x$ & $\checkmark$ & 1248512 & Fasham et al. 1989 \\
\hline 27 & $\begin{array}{l}\text { Elton Moor } \\
\text { (Derbyshire) }\end{array}$ & - & I & $\begin{array}{l}\text { Beaker, polished flint axe, } \\
\text { flint artefacts }\end{array}$ & $\checkmark$ & $x$ & 311568 & Bateman 1848, 53; Clarke 1970, 478 \\
\hline
\end{tabular}




\begin{tabular}{|c|c|c|c|c|c|c|c|}
\hline $\begin{array}{l}\text { Flowerburn Cist } \\
\text { (Highland) }\end{array}$ & - & $\mathrm{C}$ & Pottery & $\checkmark$ & $?$ & 14531 & Mackenzie 1885 \\
\hline $\begin{array}{l}\text { Forteviot Cist } \\
\text { (Perth and Kinross) }\end{array}$ & - & ?I & Copper dagger & $\sim$ & $\checkmark$ & 26565 & Noble \& Brophy 2011 \\
\hline $\begin{array}{l}\text { Freefield, Spy Hill } \\
\text { (Aberdeenshire) }\end{array}$ & - & - & Beaker & $x$ & $\checkmark$ & 18252 & Clarke 1970, 551 \\
\hline $\begin{array}{l}\text { Galley Low } \\
\text { (Derbyshire) }\end{array}$ & - & I & $\begin{array}{l}\text { Food vessel, bone pommel, } \\
\text { worked antler, flint arrowhead }\end{array}$ & $\$$ & $\checkmark$ & 310798 & Bateman 1848, 37 \\
\hline $\begin{array}{l}\text { Garton Slack } 37 \text { Burial } 6 \\
\text { (East Yorkshire) }\end{array}$ & - & $\mathrm{I}$ & $\begin{array}{l}\text { Beaker, flint dagger, jet } \\
\text { button, axe hammer }\end{array}$ & $\checkmark$ & $\checkmark$ & 64385 & $\begin{array}{l}\text { Mortimer 1905, 209; Clarke } 1970, \\
\text { 507; Clarke et al. } 1985\end{array}$ \\
\hline $\begin{array}{l}\text { Green Low } \\
\text { (Derbyshire) }\end{array}$ & M & I & $\begin{array}{l}\text { Beaker, flint dagger, flint } \\
\text { arrowheads, worked bone }\end{array}$ & $\checkmark$ & $\checkmark$ & 311568 & Bateman 1848, 59 \\
\hline $\begin{array}{l}\text { Harrowden } \\
\text { (Bedford) }\end{array}$ & - & I & Beaker, flint dagger & $x$ & $\checkmark$ & 360133 & Clarke 1970, 474 \\
\hline $\begin{array}{l}\text { Hoprig } \\
\text { (Scottish Borders) }\end{array}$ & - & I & - & $\checkmark$ & $\checkmark$ & 58716 & Hardy 1889 \\
\hline $\begin{array}{l}\text { Kirkhaugh, Barrow } 1 \\
\text { (Northumberland) }\end{array}$ & - & $\mathrm{U}$ & $\begin{array}{l}\text { Beaker, gold artefacts, flint } \\
\text { arrowhead, cores and flakes }\end{array}$ & $\checkmark$ & $?$ & 15072 & $\begin{array}{l}\text { Maryon 1936, 207-12; Needham, } \\
2012\end{array}$ \\
\hline $\begin{array}{l}\text { Lambourn Barrow } 17 \\
\text { (West Berkshire) }\end{array}$ & $\mathrm{M}$ & $\mathrm{I}$ & ?Beaker, flint dagger & $\checkmark$ & $\checkmark$ & 1455788 & $\begin{array}{l}\text { Greenwell 1877, 266; Case 1956: } 23 \text { - } \\
\text { 4; Clarke 1970, } 475\end{array}$ \\
\hline $\begin{array}{l}\text { Lesmurdie (P2) } \\
\text { (Moray) }\end{array}$ & $? \mathrm{M}$ & I & Beaker, flint flakes & $\checkmark$ & $\checkmark$ & 17297 & $\begin{array}{l}\text { Robertson 1855, 207-8; Clarke } 1970, \\
515\end{array}$ \\
\hline $\begin{array}{l}\text { Middleton-on-the-Wolds } \\
\text { (East Yorkshire) }\end{array}$ & $\mathrm{M}$ & I & $\begin{array}{l}\text { Beaker, flint dagger, jet beads, } \\
\text { bone pins }\end{array}$ & $\checkmark$ & $\checkmark$ & 64255 & Mortimer 1905, 353-4 \\
\hline $\begin{array}{l}\text { Nether Low } \\
\text { (Derbyshire) }\end{array}$ & $? \mathrm{~F}$ & I & Boar's tusk, jet bead & $*$ & $?$ & 308557 & Bateman 1861, 52 \\
\hline $\begin{array}{l}\text { Newmill } \\
\text { (Perth and Kinross) }\end{array}$ & - & $\mathrm{U}$ & Beaker, flint knife & $x$ & $\checkmark$ & 27015 & $\begin{array}{l}\text { Clarke et al. 1985, 174; Watkins \& } \\
\text { Shepherd 1980, 38-9 }\end{array}$ \\
\hline
\end{tabular}




\begin{tabular}{|c|c|c|c|c|c|c|c|}
\hline $\begin{array}{l}\text { Overton Hill 6b } \\
\text { (Wiltshire) }\end{array}$ & M & I & Beaker, bronze awl, flint knife & $\checkmark$ & $\checkmark$ & 220841 & Smith \& Simpson 1964; Clarke 1970 \\
\hline $\begin{array}{l}\text { Plas-y-Gors } \\
\text { (Powys) }\end{array}$ & - & $\mathrm{C}$ & $\begin{array}{l}\text { ?Food vessel, flint dagger, } \\
\text { flint knifes }\end{array}$ & $x$ & $\checkmark$ & 84590 & Cantrill 1898 \\
\hline $\begin{array}{l}\text { Rudston } 68 \text { Burial } 5 \\
\text { (East Yorkshire) }\end{array}$ & M & I & Bronze dagger, jet artefacts & $\checkmark$ & $\checkmark$ & 81233 & Greenwell 1877, 263-5 \\
\hline $\begin{array}{l}\text { Rudston } 68 \text { Burial } 6 \\
\text { (East Yorkshire) }\end{array}$ & $\mathrm{M}$ & $\mathrm{I}$ & Jet artefacts & $\checkmark$ & $\checkmark$ & 81233 & Greenwell 1877, 265 \\
\hline $\begin{array}{l}\text { Simondston Cairn } \\
\text { (Bridgend) }\end{array}$ & - & $\mathrm{C}$ & Food Vessels, flint knife & $\checkmark$ & $\checkmark$ & - & Fox 1939 \\
\hline $\begin{array}{l}\text { Staxton Burial } 11 \\
\text { (North Yorkshire) }\end{array}$ & $\mathrm{M}$ & $\mathrm{I}$ & Beaker & $\$$ & $\checkmark$ & 79802 & Stead 1962; Clarke 1970, 509 \\
\hline $\begin{array}{l}\text { Teindside } \\
\text { (Scottish Borders) }\end{array}$ & - & $\mathrm{C}$ & Food vessel, flint flake & $\checkmark$ & $\checkmark$ & 54071 & Greenwell 1877, 266; Rosehill 1871 \\
\hline $\begin{array}{l}\text { Townhead, Stevenston } \\
\text { (North Ayrshire) }\end{array}$ & - & $\mathrm{I}$ & Food Vessels, flint flakes & $\checkmark$ & $?$ & 41073 & Morrison 1971 \\
\hline $\begin{array}{l}\text { Udny Green } \\
\text { (Aberdeenshire) }\end{array}$ & $\mathrm{M}$ & I & $\begin{array}{l}\text { Beaker, flint knife, fragment } \\
\text { of pegmatite rod }\end{array}$ & $\checkmark$ & $x$ & 211831 & Murray and Shepherd 2007 \\
\hline $\begin{array}{l}\text { Upper Largie } \\
\text { (Argyll and Bute) }\end{array}$ & - & $\mathrm{U}$ & Beakers, flint flake knife & $x$ & $\checkmark$ & 39486 & Cook et al. 2010 \\
\hline $\begin{array}{l}\text { Ysgwennant Barrow } \\
\text { (Powys) }\end{array}$ & - & $\mathrm{C}$ & Beakers, flint knife & $\checkmark$ & $\checkmark$ & 306807 & Clarke 1970, 524; Day 1972 \\
\hline
\end{tabular}

\section{Key to Table 1}

Burial Rite: I Inhumation, C Cremation, U Body Unpreserved

Striker: $\checkmark$ present, $\boldsymbol{x}$ absent, $?$ possible presence

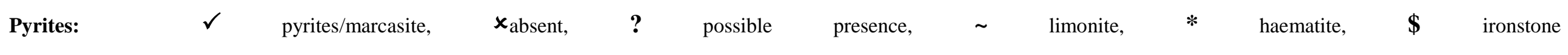


Table 2: Radiocarbon dates from British strike-a-light burial sites

Radiocarbon dates have been calibrated with OxCal 4.2 using the IntCal 13 atmospheric calibration curve and are quoted as 95\% probability ranges (Bronk Ramsey 2009). Beaker phases are taken from Needham (2012).
SITE
C14 \pm
Cal. BC (95\%)
Material
Laboratory Number

PRIMARY BEAKER

$\begin{array}{lrrrrr}\text { Chilbolton } & 3935 & 32 & 2560-2300 & \text { human bone } & \text { OxA-V-2271-35 } \\ \text { Upper Largie } & 3915 & 40 & 2560-2290 & \text { charcoal } & \text { SUERC-15646 } \\ \text { Amesbury Archer } & 3895 & 32 & 2470-2290 & \text { human bone } & \text { OxA-13541 } \\ \text { Dornoch Nursery } & 3850 & 40 & 2460-2200 & \text { human bone } & \text { GrA-26515 } \\ \text { Boscombe 25004 } & 3845 & 27 & 2460-2210 & \text { human bone } & \text { OxA-13624 }\end{array}$

PHASE 2 BEAKER

$\begin{array}{llllll}\text { Udny Green } & 3795 & 28 & 2330-2140 & \text { human bone } & \text { OxA-V-2243-47 } \\ \text { Easton Lane } & 3791 & 30 & 2340-2140 & \text { human bone } & \text { OxA-V-2271-36 } \\ \text { Acklam Barrow K4 } & 3774 & 36 & 2330-2040 & \text { human bone } & \text { OxA-V-2197-50 } \\ \text { Lesmurdie } & 3770 & 33 & 2290-2050 & \text { human bone } & \text { OxA-13098 } \\ \text { Staxton Burial 11 } & 3765 & 30 & 2290-2050 & \text { human bone } & \text { SUERC-26198 } \\ \text { Forteviot Cist } & 3690 & 30 & 2200-1980 & \text { charcoal } & \text { SUERC-29196 } \\ \text { Green Low Barrow } & 3660 & 30 & 2140-1950 & \text { human bone } & \text { SUERC-26164 }\end{array}$

PHASE 3 BEAKER/BRONZE AGE

$\begin{array}{lccccc}\text { Dunfermline Cist 3 } & 3581 & 40 & 2040-1780 & \text { human bone } & \text { SRR-292 } \\ \text { Bulford, Torstone } & 3475 & 30 & 1890-1700 & \text { human bone } & \text { SUERC-32173 } \\ \text { Ysgwennant Barrow } & 3423 & 82 & 1940-1530 & \text { charcoal } & \text { Birm-85 } \\ \text { Barrow Hills Grave 203 } & 3360 & 50 & 1760-1510 & \text { human bone } & \text { BM-2700 } \\ \text { Amesbury G58 } & 3310 & 80 & 1870-1420 & \text { charcoal } & \text { HAR-6226 }\end{array}$


Table 3: Stable isotope data from strike-a-light burial sites. Data are from Chenery and Evans (2011) and Parker Pearson et al. (in press)

\begin{tabular}{|c|c|c|c|c|c|c|c|c|}
\hline Site Name & BPP no & $14 C$ (cal. 95\%) & $C$ & $N$ & $S$ & $O$ & $S r$ & Notes \\
\hline Acklam Barrow K B 4 & SK 61 & $2340-2040 \mathrm{BC}$ & -21.1 & 10.9 & 11.7 & 16.8 & .711765 & $\begin{array}{l}\text { Migrant from outside Britain }(\mathrm{O}) \text {, from region with } \\
\text { Palaeozoic rocks }(\mathrm{Sr})\end{array}$ \\
\hline Amesbury Archer & SK 301 & $2480-2280 \mathrm{BC}$ & -21.0 & 10.4 & 10.3 & 16.2 & .710340 & Migrant from outside Britain $(\mathrm{O})$ \\
\hline Barrow Hills Ring Ditch & SK 267 & - & -21.3 & 9.8 & 5.4 & 18.0 & .708790 & Local (skeleton analysed is Ring Ditch 17) \\
\hline Boscombe 25004 & SK 300 & $2460-2210 \mathrm{BC}$ & -21.1 & 10.2 & 11.5 & 17.5 & .713436 & $\begin{array}{l}\text { Migrant from region with Palaeozoic rocks }(\mathrm{Sr}) \text {, could be } \\
\text { within Britain }\end{array}$ \\
\hline Chilbolton & SK 164 & $2570-2300 \mathrm{BC}$ & -21.5 & 10.5 & 12.1 & 18.5 & .709093 & Local \\
\hline Easton Lane & SK 166 & 2336-2136 BC & -21.0 & 10.6 & 13.6 & 18.1 & .708827 & Local \\
\hline Green Low Barrow & SK 198 & 2140-1950 BC & -21.9 & 11.1 & 8.5 & 18.5 & .708981 & Local \\
\hline Staxton Burial 11 & SK 274 & $2290-2040$ BC & -21.4 & 10.9 & 13.9 & 18.1 & .709936 & $\begin{array}{l}\text { Migrant from non-chalk geology ( } \mathrm{Sr} \text { ), could be within } \\
\text { Britain; n.b. Staxton Burial } 4 \text { is continental migrant }\end{array}$ \\
\hline
\end{tabular}

\section{KEY to Table 3}

BPP no - skeleton number from beaker People Project (Parker Pearson et al., in press)

$\boldsymbol{C}$ - Carbon $\boldsymbol{N}$ - Nitrogen $\boldsymbol{S}$ - Sulphur $\boldsymbol{O}$ - Oxygen $\boldsymbol{S r}$ - Strontium 


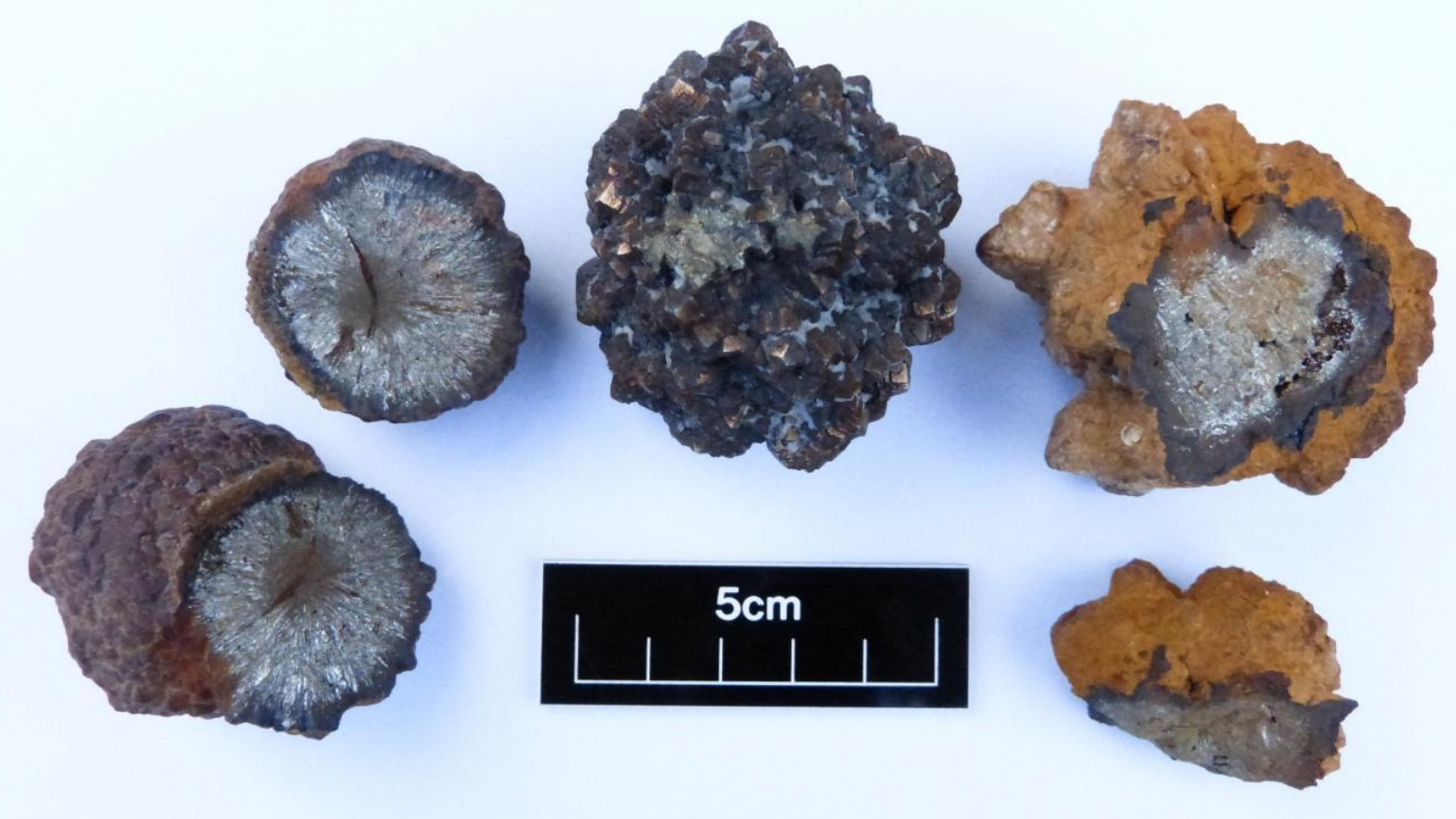

Illus. 1 Whole pyrite nodules. In centre, whole pyrite extracted from chalk bedrock; to the right a freshly broken pyrite nodule extracted from chalk showing oxidised exterior and to the left, a pyrite nodule retrieved from a natural beach deposit and broken (@ Anne Teather)

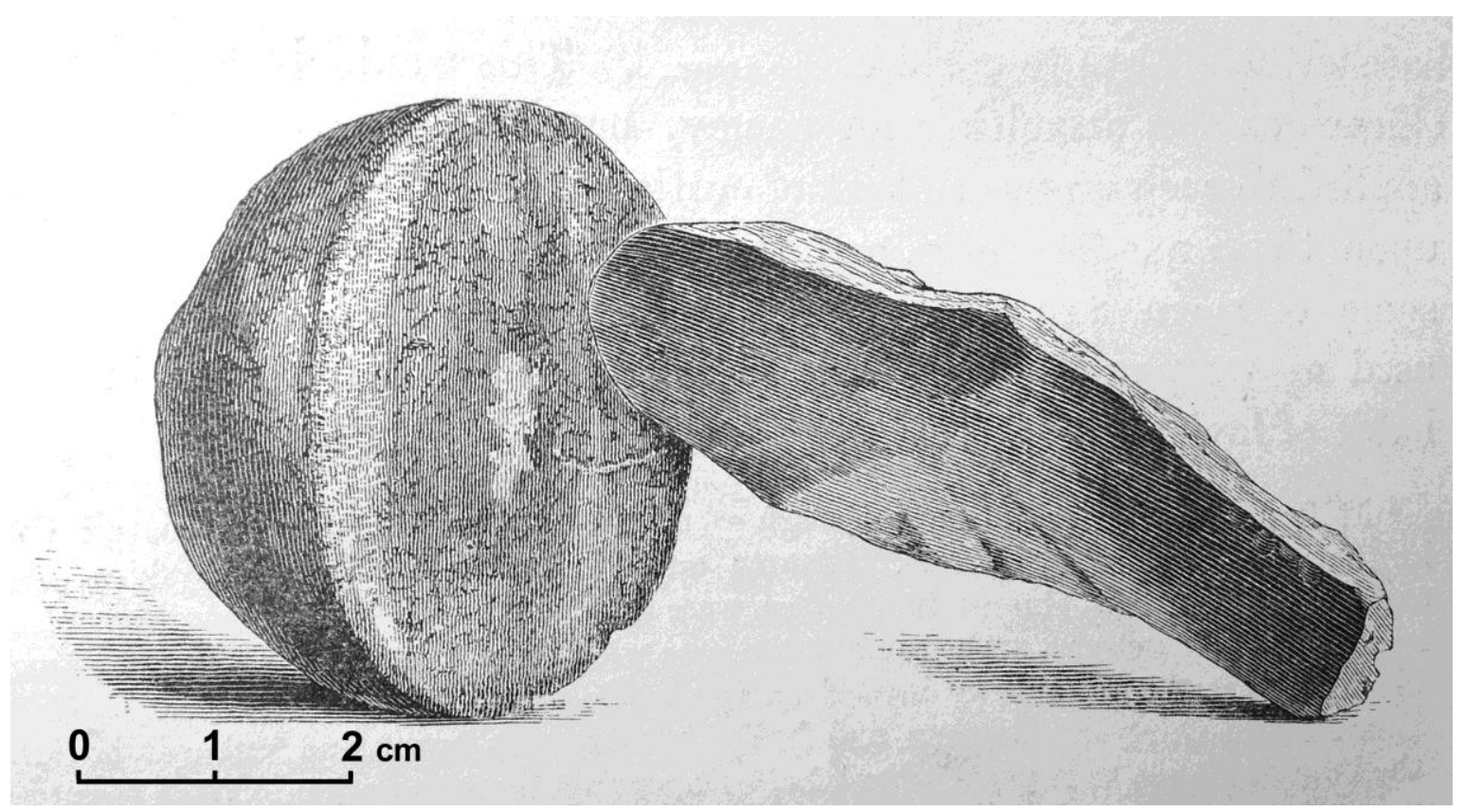

Illus. 2 Pyrite nodule and flint striker from Rudston (from Greenwell, 1877, 41) 


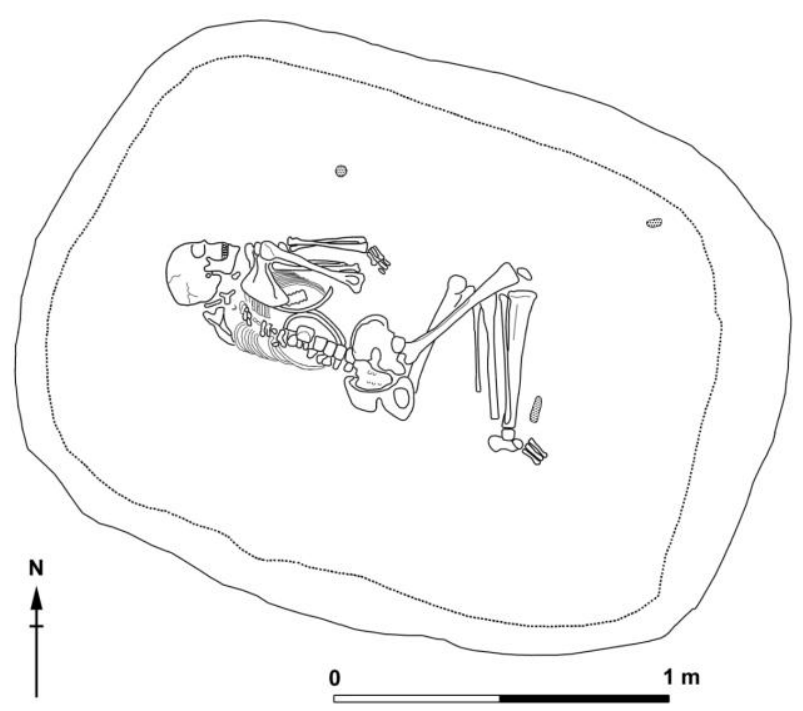

Illus. 3 Amesbury Archer grave with the locations of strikers and stone noted (other grave-goods not illustrated; after Fitzpatrick 2011, figs 28 and 29). One flint striker at the feet, one at the north-east of the grave with the pyrite nodule in front of the chest

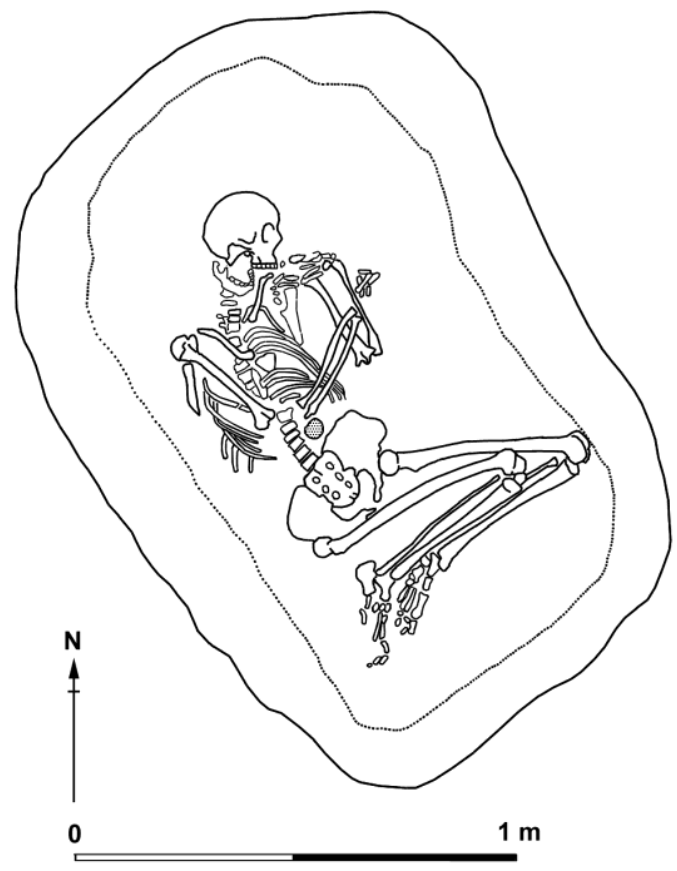

Illus. 5 Barrow Hills, Radley, Grave 203 with pyrite nodule shown at waist, other grave-goods not illustrated (after Barclay and Halpin 1999, fig 4.76) 


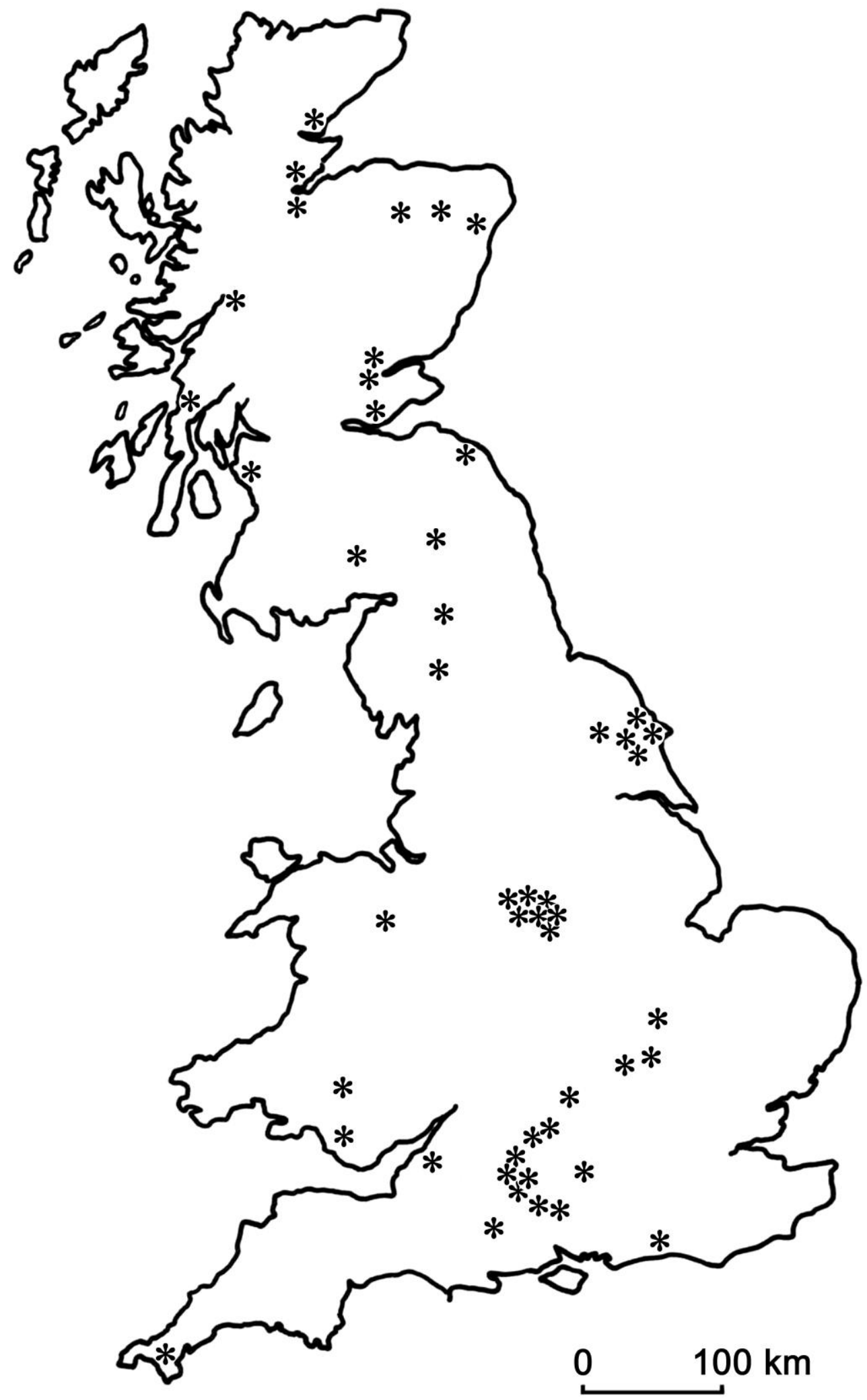

Illus. 4 Distribution of strike-a-light burials in Britain 